\title{
Black Bears (Ursus Americanus) as Possible Vectors of Bi-directional Nutrient Transfer in Marine and Terrestrial Systems Inferred from their Late Summer Diets
}

\author{
Sara Wickham and Beatrice Proudfoot ${ }^{*}$ \\ University of Victoria \\ swickers@gmail.com
}

\begin{abstract}
American black bears (Ursus americanus) are highly opportunistic omnivores and tend to forage selectively depending on the seasonal abundance of food items. We collected and analyzed 22 scats from various beaches and forests near Bamfield B.C. and determined that in late summer, bears in the area rely heavily on Gaultheria shallon berries. Hemigrapsus spp., Talitrid amphipods and seaweeds were also fed on by black bears in the area in late August. Marine-derived organisms were found in scats collected in the forest, and terrestrial-derived organisms were found in scats collected on beaches, suggesting that there is a bi-directional transfer of marine and terrestrial nutrients and biomass.
\end{abstract}

Keywords: Gaultheria shallon; scat; salal; subsidy; Talitrid amphipod; Ursus americanus vancouveri

\footnotetext{
"First and foremost, we would like to thank Dr. Caroline Fox for her guidance and constant support throughout this project and the course. Thank you to our wonderful T.A., Logan Wiwchar for all his hard work and support throughout the course, and for always ensuring we had ample supplies and were safely outfitted for the field. Thank you to Dr. Barb Beasley for a wonderful two weeks of exploring the terrestrial realm and for sharing her knowledge of the area with us. Thank you to the Bamfield Marine Sciences Center for providing us with the amazing opportunity to explore our own scientific potential. Finally, thank you so much to all our classmates for the endless laughs, support and inspiration.
} 


\section{INTRODUCTION}

$\mathrm{T}$ HE American BLACK BEAR (Ursus americanus, hereafter referred to as bears) is an abundant species established throughout North America. The black bear population in British Columbia is estimated between 120,000 and 160,000 individuals (Hristienko and McDonald, 2007) with a density of one bear per five kilometers squared (Horn, 2009). British Columbia's black bear population is comprised of five subspecies. One subspecies, Ursus americanus vancouveri, is endemic to Vancouver Island, the only subspecies of black bear present on Vancouver Island (BC Ministry of Environment, 2001), and common in and around Bamfield, British Columbia.

Although black bear populations in B.C. are at healthy and stable levels, understanding their diet and habits and preserving their habitats is an important objective for conservationists. The role of black bears in many ecosystems is incredibly important. They are vectors for transport of nitrogen into forests (often through deposition of salmon carcasses; Quinn et al., 2009), and are valuable indicator species that are very sensitive to changes in salmon run sizes and shifts in vegetation availability - two of their most important dietary components (Horn, 2009).

Black bears such as U. americanus vancouveri are opportunistic omnivores (Horn, 2009). Their feeding habits vary depending on the abundance and availability of food items (Howes, 1999). If accessible, bears will selectively consume invertebrates, rodents, fish, and carrion (Howes, 1999) because these foods have higher nutritional values than vegetation (Smith and Partridge, 2004). In spite of the high nutrients that animal matter provides, the dominant portion of the diet of black bears is vegetation: plant shoots and roots, grasses, forbs, and fruits (Howes, 1999; MacHutchon, 1999), all of which are abundant in different seasons on Vancouver Island.

Little attention has been paid to these bears' interactions with intertidal and coastal areas (Howes, 1999; Smith and Partridge, 2004). Vancouver Island has 3,400 kilometers of productive coastline and $U$. americanus vancouveri has often been observed foraging in the inter- 
tidal zone (MacHutchson, 1999; Howes, 1999; personal observations). Intertidal invertebrates such as shore crabs (Hemigrapsus spp.), mussels (Mytilus spp.), clams (Siliqua spp.), barnacles (Balanus spp.), marine worms (Nereis spp.), Talitrid amphipods, and fish (Ammodytes spp.) could represent a significant portion of their nutritional and energetic resources, especially during the spring and early summer seasons when the bears are eager to gain weight after hibernation (Smith and Partridge, 2004).

In late summer, the diet of black bears begins to shift toward ripening fruits and berries (MacHutchon, 1999). Much research has been performed on the diet of black bears in Clayoquot Sound, which is located approximately 40 nautical miles north of Bamfield, B.C. These bears have been observed consuming salal berries (Gaultheria shallon), Salmonberries (Rubus spectabilis), and blueberries (Vaccinium spp.) (Howes, 1999, MacHutchon, 1999, personal observations) during the month of August. However, the late summer diet of black bears inhabiting Barkley Sound, near Bamfield B.C., has not been explored.

The purpose of this study is to determine the late summer diet of coastal U. americanus vancouveri near Bamfield, B.C. Knowledge of this diet can help to understand the complexities of the food web in this region and to explore whether marine and terrestrial-derived nutrients and biomass are being transferred to and from beaches and forests via black bear faeces. If a bidirectional transfer of nutrients is occurring, future studies could perhaps explore if the scats themselves are a possible source of nutrients for beach ecosystems.

A non-invasive method to explore black bear diets and the marineterrestrial interactions they may be a part of is to examine the distribution and composition of black bear faeces in intertidal and forest areas. Black bears have a simple and short digestive tract that lacks complex microbial flora and inhibits efficient digestion and as a result, items in the scats are often relatively identifiable (Howes, 1999). Scats are incredibly valuable resources for study that can allow researchers to gain insight into the diet, movement and range of animals (Darimont et al., 2008). Analysis of scats involves identifying food items 
and relating these items to diet through frequency and volume calculations (Baldwin and Bender, 2009), and inferring the diet of the animal based on faecal residue.

By deriving a portion of their diets from intertidal and marine sources and travelling into forests, bears are effectively acting as vectors of nutrient transport into the forest. This scenario may be best demonstrated in the fall through the transport of nitrogen in the form of Pacific salmon (Oncorhynchus spp.) to riparian forests by bears. The salmon carcasses that bears transport in to the forests can increase foliar nitrogen by an average of $14 \%-60 \%$, thus increasing vegetation productivity in riparian forests (Hocking and Reynolds, 2012). This uni-directional flow of marine-derived nutrients is a well documented spatial subsidy (Reimchen 2000; Howes, 1999) and has profound impacts for other species such as vertebrate and invertebrate scavengers (Hocking and Reynolds, 2012), birds (Field and Reynolds, 2011), and terrestrial flies (Hocking and Reimchen, 2006) that feed on the salmon carcasses.

Bears also transport a large amount of marine derived nitrogen into forests through their urine. The nitrogen in the bears' urine is more accessible to terrestrial plants than the nitrogen bound within the salmon carcasses that the bears bring into the forest (Helfield and Naiman, 2006).

However, the reciprocal flow of terrestrial-derived nutrients in the form of digested vegetation and berries from the forest to the intertidal zone and the possible impacts resulting from this movement are often ignored. Before we consider whether the digested vegetation and berries in the scat is a potential subsidy for beach ecosystems, we first need to establish whether a noteworthy bidirectional transfer exists. We can then explore the possible impacts of this potential transfer. The scat on the beaches may be providing a unique and brief influx of nutrients to the high intertidal and supratidal zones, which may benefit a number of scavengers and invertebrates. If the bidirectional transfer does exist, and if the poorly digested berries and plant matter in the scat can be proven to be an important subsidy for beach ecosystems, we can use this information to preserve the habitat that 
connects forests and beaches in order to allow this bidirectional flow of nutrients to occur.

\section{MATERIALS AND METHODS}

From August 19-23, 2013 we collected a total of 39 scats from locations near Bamfield, B.C., Canada $\left(48.83^{\circ} \mathrm{N}, 125.14^{\circ} \mathrm{W}\right)$. Bamfield Inlet, Grappler Inlet, Kelp Bay, First Beach, and Second Beach were chosen based on sightings and reports of bears foraging in the area. At each site we surveyed $500 \mathrm{~m}$ of the medium and high intertidal zones and collected bear scat within these zones. We scouted the forest edge of the $500 \mathrm{~m}$ beach transect for any obvious bear trails. We followed these trails for as long as possible (minimum length $=10 \mathrm{~m}$ ) up to a maximum of $200 \mathrm{~m}$ and collected any identifiable bear scat. Edges created by waterways such as streams and creeks are popular corridors for black bear travel (Cervinka et al., 2011) and thus we considered these streams and creeks as bear trails and followed for a maximum of $200 \mathrm{~m}$. The Bamfield Inlet beach site was bordered by private property and bear trails were thus unrecognizable. We established a "forest transect" of 500m along South Bamfield Road and the Huu-ay-aht Community Forest Logging Road to compensate.

We collected scats into zip lock baggies labeled with dates and GPS coordinates. Because we found a high number of scats in close proximity in certain sites, several scats were discarded in order to reduce any bias that might lead to the over representation of a certain food item being consumed by an individual bear (Dahle et al., 1998). We discarded any scats estimated to be older than two weeks, which we determined by examining the scat for fungus and degradation. After these corrections, we used 22 scats for analysis.

Within four hours of collection we placed the scats in a $-18^{\circ} \mathrm{C}$ freezer and froze them for a minimum of 24 hours. We then hand mixed the scats once thawed and washed the scat in a $1 \mathrm{~mm}$ mesh sieve. We used three $6 \mathrm{ml}$ sub-samples of each scat (measured via wa-

\footnotetext{
${ }^{1}$ For a more detailed breakdown of the sample and discard rationale, see http://142.25.56.9/InmagicGenie/DocumentFolder/proudfoot_wickham_cbc2013.pdf
} 
ter displacement) for scat composition analysis. We then poured the sub-samples over $1 \mathrm{~cm}^{2}$ grids and observed them through a $0.67 \mathrm{X}-4 \mathrm{X}$ stereo microscope. We identified and sorted scat components into the following categories: seaweed (includes macroalgae of Phaeophyta, Rhodophyta and Chlorophyta), Zostera spp. (seagrasses), Talitrid amphipods, Hemigrapsus spp. (shore crabs), insects, graminoids (grasses and sedges), terrestrial plant components (including leaves, roots, twigs, bark and stems), Gaultheria shallon (salal berries, flowers, berry stems and seeds), Vaccinium sp., insect larvae, and rocks. Visual estimations of percent volumes of scat items have been found to correspond well with measurements of overall volumes (Mattson et al., 1991 and Persson et al., 2001). We visually estimated the percent volume of the scat components in each subsample, averaged these values and compared scats collected from forest sites with those collected from beach sites.

We summarized the items present in each scat in terms of Frequency of Occurrence (FO) and percent Faecal Volume (FV) (e.g. Fox et al., 2013):

- $\mathrm{FO}=$ (number of scats containing item $\mathrm{x} /$ total number of scats) $\mathrm{X} 100$

- $\mathrm{FV}=$ (mean volume of food item $\mathrm{x} /$ total faecal volume) $\mathrm{X} 100$

Because black bear foods differ in their digestibility (Mealy, 1974), measurements of faeces composition may not accurately reflect the diet of the bear. The dietary contribution of highly-digestible items, such as animal matter and, in this case, amphipods, insects and shore crabs, are often underestimated, and the contribution of poorly digestible items, such as graminoids, are often overestimated (Persson et al., 2001). We adapted and applied Correction Factors (CFs) developed by Hewitt and Robbins (1996) and used by Fox et al. (2013) to the FV calculations to estimate the original Estimated Dietary Content (EDC, measured in percent) from the FV.

Correction factors help account for biases created by the differing digestibilities of food items (i.e. animal matter is more digestible than graminoids; Hewitt and Robbins, 1996), which could lead to under- or 
overestimations of dietary items. Knowledge of the EDC is pertinent when estimating nutrient transfer from forest to beach and vice-versa, as some nitrogenous compounds obtained from ingestion of marine resources may be expelled in urine (Hellgren, 1995) and would not be accounted for in FV calculations. The CFs used in this study were:

Table 1: Correction factors

\begin{tabular}{ll}
\hline & \\
Seaweeds & 0.24 \\
Zostera & 0.24 \\
Talitrid amphipods & 1.1 \\
Hemigrapsus sp. & 1.1 \\
Insects & 1.1 \\
Graminoids & 0.24 \\
Terrestrial plants & 0.24 \\
G. shallon & 0.54 \\
Vaccinium sp. & 0.54 \\
Insect larvae & 1.25 \\
\hline
\end{tabular}

We did not include gravel and rocks in EDC calculations as they are assumed to have been inadvertently ingested during foraging and do not contribute to any bi-directional nutrient transfer, nor provide any energy to the bears.

\section{Results}

\section{Hard part scat analysis of all scats $(n=22)$}

Analysis of hard part scat composition (solid components of the scat that did not pass through the $1 \mathrm{~mm}$ sieve) and percent Faecal Occurrence (FO) calculations reveal that G. shallon was found in $95.45 \%$ of all scats $(\mathrm{n}=22)$, and that terrestrial plant parts $(77.27 \%)$, insects (45.45\%) and Zostera spp. (36.36\%) were also common dietary items for black bears in late August 2013 (Table 2). 
Table 2: Percent Frequency of Occurrence (FO) values for various items in Ursus americanus vancouveri scats collected from various locations near Bamfield, B.C.

\begin{tabular}{llll} 
Scat Item & $\begin{array}{l}\text { Beach Scats } \\
(\% \mathrm{FO} ; \mathrm{n}=13)\end{array}$ & $\begin{array}{l}\text { Forest Scats } \\
(\% \mathrm{FO} ; \mathrm{n}=19)\end{array}$ & $\begin{array}{l}\text { Total scats } \\
(\% \mathrm{FO} ; \mathrm{n}=22)\end{array}$ \\
\hline Seaweed & 23.08 & 33.33 & 27.27 \\
Zostera spp. & 38.46 & 33.33 & 36.36 \\
Talitridae & 30.77 & 22.22 & 27.27 \\
Hemigrapsus spp. & 7.69 & 11.11 & 4.55 \\
Insects & 53.85 & 33.33 & 45.45 \\
Graminoids & 15.38 & 25.00 & 18.18 \\
Terrestrial plant parts & 84.62 & 66.67 & 77.27 \\
Gaultheria shallon & 100.00 & 88.89 & 95.45 \\
Vaccinium spp. & 7.69 & 11.11 & 9.09 \\
Insect larvae & 0.00 & 11.11 & 4.55 \\
Rocks & 38.46 & 11.11 & 27.27 \\
\hline
\end{tabular}

Percent Faecal Volume (FV) calculations indicate that on average, the most abundant items found in scats were: G. shallon $(\bar{x}=73.73 \%$ \pm 7.03 standard error (SE)), terrestrial plant parts $(\bar{x}=7.16 \% \pm 3.44 \mathrm{SE})$ and seaweeds $(\bar{x}=5.70 \% \pm 3.71 \mathrm{SE} ; \mathrm{n}=22$; Figure 1$)$. Using correction factors, we approximated the diet of these black bears by calculating the mean Estimated Dietary Content (EDC) of each item and determined that in late August 2013, 78.21\% \pm 3.80 SE of their diet was composed of G. shallon, $5.51 \% \pm 3.80 \mathrm{SE}$ is composed of Hemigrapsus spp. and $3.72 \% \pm 1.11 \mathrm{SE}$ is composed of Talitrid amphipods. Graminoids $(1.18 \% \pm 0.43 \mathrm{SE})$, terrestrial plant parts $(3.38 \% \pm 0.83 \mathrm{SE})$ and Zostera spp. $(1.60 \% \pm 0.28 \mathrm{SE})$ were relatively small components of the diet of these black bears (Figure 2). 
Figure 1: Mean percent Faecal Volumes of dietary components of Ursus americanus vancouveri scats collected from various locations near Bamfield, B.C. $(n=22, S E=$ standard error $)$.

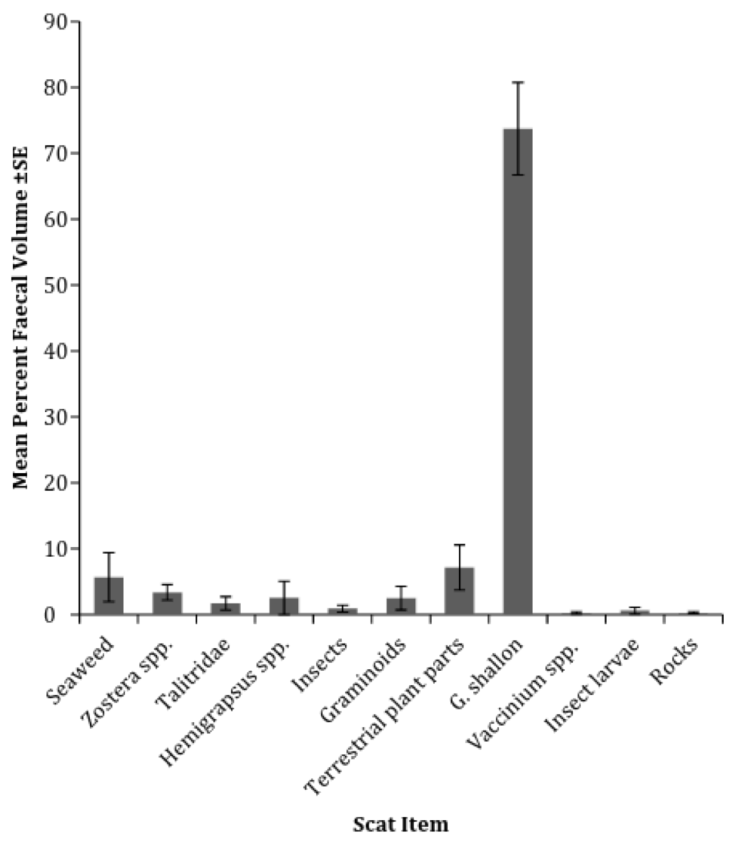


Figure 2: Estimated Dietary Content of dietary components of Ursus americanus vancouveri scats collected from various locations near Bamfield, B.C. $(n=22, S E=$ standard error $)$.

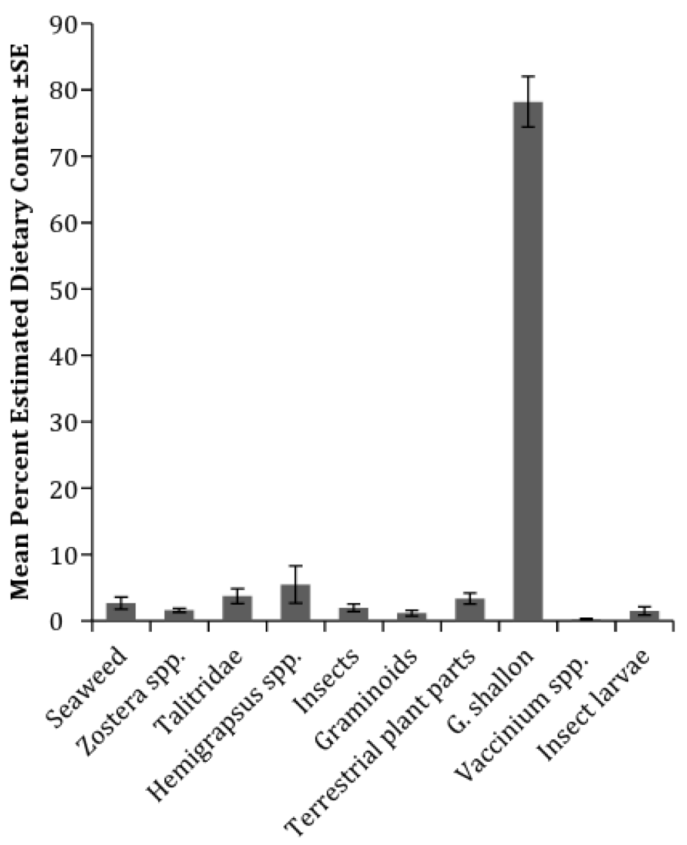

Diet Item 


\section{Hard part scat analysis of forest $(n=9)$ and beach scats $(\mathrm{n}=13)$}

Hemigrapsus spp. and seaweed occurred more frequently in scats collected from the forest $(\mathrm{FO}=11.11 \%$ and $33.33 \%$, respectively; $\mathrm{n}=9$ ) compared to those collected at the beach $(\mathrm{FO}=7.69 \%$ and $23.08 \%$, respectively; Table 2). Talitrid amphipods, insects and rocks occurred more frequently in beach scats (Table 2).

Percent Faecal Volume (FV) comparisons between scats collected in the beach and the forest (Figure 3) indicate that on average, scats collected from the beach had notably higher abundances of $G$. shallon and Talitrid amphipods. Scats collected from the forest had higher abundances of Hemigrapsus spp, seaweed, Zostera spp., terrestrial plant parts, insects and insect larvae.

Comparisons between mean EDCs of scats found in forest and beach sites (Figure 4) illustrates that scats collected from beaches were the product of diets composed of higher proportions of $G$. shallon and Talitrid amphipods, compared to scats collected from forest sites. Scats collected from forest sites were the product of diets composed of higher proportions of marine-derived organisms such as Hemigrapsus spp. and seaweed, as well as terrestrial plants, insects and insect larvae compared to scats collected from beach sites.

\section{Discussion}

In late August 2013, G. shallon berries were ripe and abundant in the Bamfield, B.C. area (personal observation) and were found to be a dominant food source for the black bears of the region. The high abundance and availability of $G$. shallon berries may reduce foraging costs for the bears, as the bears do not have to travel as far to acquire food resources (Howes, 1999).

The volume of $G$. shallon berries in black bear scats in Clayoquot Sound dramatically shifts from approximately $8 \%$ FV in July to approximately 67\% FV in August (MacHutchon, 1999). Mean percent FV values of $G$. shallon berries in black bear scats sampled in late 
Figure 3: Mean percent Faecal Volumes of dietary items in Ursus americanus vancouveri scats collected from beach and forest sites near Bamfield, B.C. (forest scats: $n=9$; beach scats $n=13 ; S D=$ standard deviation).

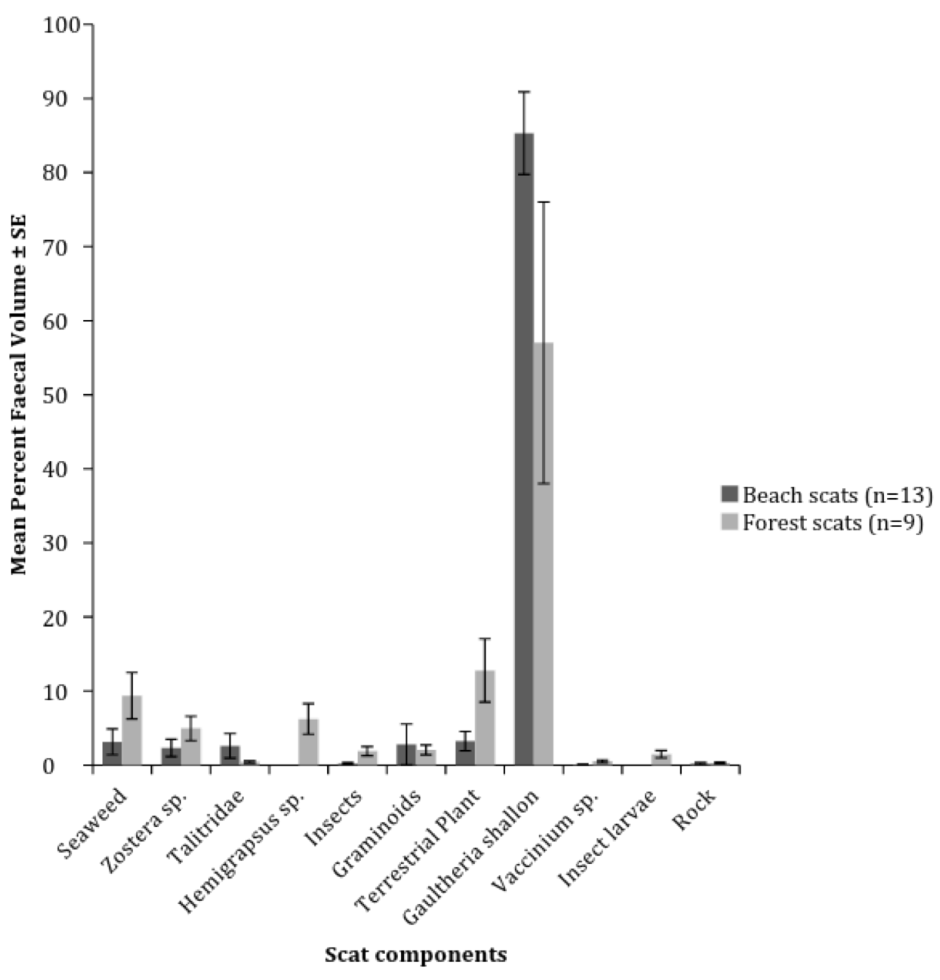


Figure 4: Estimated Dietary Content (EDC) of dietary items in Ursus americanus vancouveri scats collected from beach and forest sites near Bamfield, B.C. (forest scats: $n=9$; beach scats $n=13 ; S D=$ standard deviation).

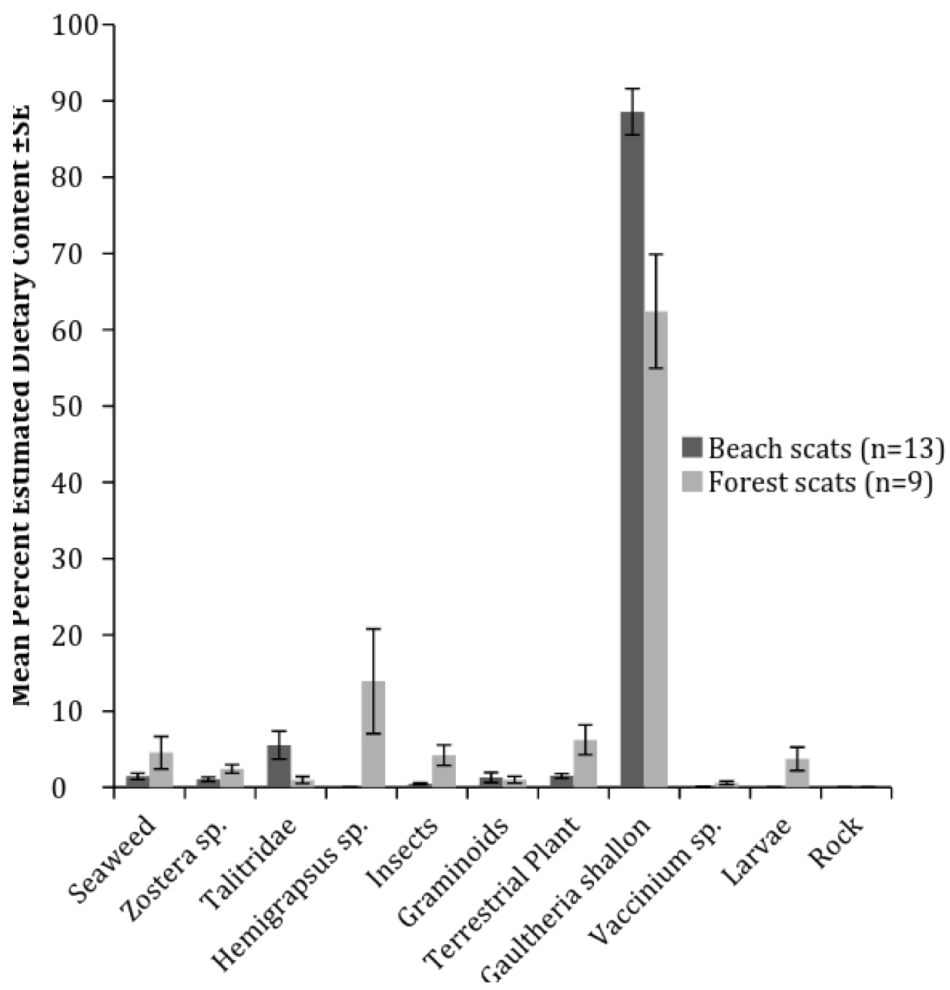


August from Bamfield and Clayoquot Sound are similar (Bamfield = $73.73 \% \pm 7.03 \mathrm{SE}$, Clayoquot $=67 \%$ ), which suggests that black bears in Barkley Sound and Clayoquot Sound may share some late summer foraging behaviours and have similar late summer diets that are dominated by $G$. shallon berries.

Hemigrapsus spp., Talitrid amphipods and seaweeds were also fed on by Bamfield black bears in late August; however Hemigrapsus spp. was found in only one scat, and the FV of Hemigrapsus spp. in this scat was $56.13 \%$. This relatively high FV value in a single scat has a considerable effect on the EDC of Hemigrapsus spp., and likely overestimates the importance of Hemigrapsus spp. in the August diet of black bears in the study area. We have observed black bears foraging on Hemigrapsus spp. in rocky intertidal areas near Bamfield in July and early August. However, because G. shallon berries are so abundant and available in late summer, and because black bears are opportunistic in their feeding behaviours (Horn, 2009), it appears they shift their focus to the highly abundant G. shallon berries.

Talitrid amphipods were present in $28 \%$ of scats, however it was observed that many small amphipod fragments were too small to be captured in the $1 \mathrm{~mm}$ sieve and were subsequently lost during the washing process. Therefore, the percent FV and EDC of Talitrid amphipods are likely underestimated. Furthermore, all scats that contained seaweed $(n=5)$ corresponded with all but one scat containing amphipods. Black bears are known to incidentally ingest seaweed and seagrass when foraging for herring eggs (Fox et al., 2013). The presence of seaweeds and amphipods in the same scat suggests that bears in the study area may be incidentally ingesting seaweed while they forage for amphipods under the seaweed wrack. Additionally, due to the small sample size, and to the fact that a single scat had a seaweed FV value of $80.28 \%$, the importance of seaweeds in the late summer diet of black bears in Bamfield is likely overestimated while the importance of amphipods is likely underestimated. The scat containing amphipods but no seaweed contained 9.9\% FV Zostera spp. Amphipods are known to graze on epiphytic algae growing on Zostera spp. (Jaschinski and Sommer, 2010). If we consider that consuming 
Zostera spp. typically provides bears with relatively little energy compared to consuming animals (Baldwin and Bender, 2009), the presence of Zostera spp. in $36.36 \%$ of scats may also be due to incidental ingestion as bears forage for amphipods. The late summer diet of black bears in Bamfield also includes minor contributions from other terrestrial plants, graminoids, insects, insect larvae and Vaccinium spp., although these contributions are slight compared to the large contribution from G. shallon berries. However, like the Talitrid amphipods, insect fragments may have been too small to be captured in the $1 \mathrm{~mm}$ sieve, so the percent EDC of insects in the late summer diet may also be underestimated.

This brief snapshot of the late summer diet of black bears in Bamfield, BC captures an important shift to a diet dominated by G. shallon berries that persists into October for bears living and foraging in similar habitats, such as Clayoquot Sound (MacHutchon, 1999).

Our results suggest that to some extent a bi-directional transfer of terrestrial and marine derived subsidies is occurring via bear faeces during late August in Bamfield B.C. Due to our small sample size $(\mathrm{n}=22)$, it is difficult to determine the magnitude of the bidirectional transfer. However, future studies could explore the possible influence this transfer could have on beach ecosystems.

Bi-directional transfer of marine and forest biomass and nutrients can be a major influence on the ecosystems that receive them (McCauley et al., 2012). The predominate source of the terrestrialderived nutrients and biomass in our study was G. shallon berries, which were present in $100 \%$ of the scats collected from beach sites. Many of the G. shallon seeds and berries in the scats were intact, and may be a potential source of nutrients for beach-dwelling rodents, birds and invertebrates. Rodents are known to scavenge for seeds in bear scats (Enders and Vander Wall, 2012), and we noted the presence of live isopods in a number of scats, as well as scats that appeared to have been disturbed by some sort of animal. When fruits are available in large quantities, large bears are capable of ingesting up to 70,000 individual berries, defecating 7-10 times per day and moving an average linear distance of $2.1 \mathrm{~km}$ (Nowak and Crone, 2006). Thus, 
black bears in the Bamfield area are potentially transporting an immense amount of terrestrial biomass and nutrients from forests to beaches. Furthermore, because beaches are important travel corridors for bears (MacHutchon, 1999), bears may be depositing more scats in general on frequently traveled beaches.

Because G. shallon berries dominate the black bear diet in late $\mathrm{Au}-$ gust, we observed more terrestrial-to-marine transfer, whereas if we were to conduct a similar study in September and October, when crustaceans, mussels and insects are likely common animal foods in the bears' diet (MacHutchon, 1999), or in the spring, when bears consume large amounts of herring eggs (Fox et al., 2013), we may perhaps observe more marine-to-terrestrial transfer. This bi-directional transfer of marine and terrestrial-derived resources in forest and beach sites is likely in flux throughout the year, and depends on the seasonal food habits of the bears.

Black bears in the Bamfield area were also transporting G. shallon berries and seeds within the forest itself. G. shallon was found in $88.9 \%$ of scats collected in the forest. When berry seeds pass through the digestive system of a bear, the seeds are removed from the fruit, which has a positive impact on germination relative to fruits that simply fall from the parent plant (Nowak and Crone, 2012). Bears are potentially transporting and depositing thousands of G. shallon seeds throughout the forest in our study area.

\section{Conclusion}

Analysis of the composition and distribution of black bear scats near Bamfield B.C. is a powerful method that has allowed us to gain insight into the late summer diet and movement of black bears in the area. Understanding and documenting the seasonal diets of coastal black bears can inform conservation efforts that aim to protect critical habitat. Finally, by exploring the marine-terrestrial interactions that black bears are a part of, we can begin to understand how complex and interwoven these two systems are. 


\section{REFERENCES}

Baldwin, R.A. \& Bender, L.C. (2009). Food and nutritional components of diets of black bear in Rocky Mountain National Park, Colorado. Canadian fournal of Zoology, 87, 1000-1008. ${ }^{\text {http://dx.doi.org/1 }} 0.1139 / 209-088$

British Columbia Ministry of Environment, Land and Parks. (2001). Black bears in British Columbia: ecology, conservation and management.

Breck, S.W., Lance, N. \& Seher, V. (2009). Selective foraging for anthropogenic resources by black bears: minivans in Yosemite National Park. Fournal of Mammology, 90(5), 1041-1044. $\begin{aligned} & \text { http://dx.doi.org/10.16 } \\ & 44 / 08-m a m m-a-056.1\end{aligned}$

Cervinka, J., Salek, M., Pavluvcik, P. \& Kreisinger, J. 2011. The finescale utilization of forest edges by mammalian mesopredators related to patch size and conservation issues in Central European farmland. Biodiversity and Conservation, 20, 3459-3475. http://dx.doi.org/10.100

Dahle, B., Sorensen, O.J., Wedul, E.H., Swenson, J.E., \& Sandegren F. (1998). The diet of brown bears Ursus arctos in central Scandinavia: effect of access to free ranging domestic sheep Ovis aries. Wildlife Biology, 4, 147-158.

Darimont, C.T., Reimchen, T.E., Bryan, H.M., \& Paquet, P.C. (2008). Faecel-centric approaches to wildlife ecology and conservation: methods, data, and ethics. Wildlife Biology., 4(2), 73-87. $2461 /$ wbp.2008.4.7

Enders, S.E. \& Vander Wall, S.B. (2012). Black bears (Ursus americanus) are effective seed dispersers, with a little help from their friends. Oikos., 121, 589-596. http://dx.doi.org/10.1111/j.1600-0706.2011.19710.x Field, D.F. \& Reynolds, J.D. (2011). Sea to sky: impacts of residual salmon-derived nutrients on estuarine breeding bird communities. Proceedings of the Royal Society: Biological Sciences B, 278, 3081-3088. http://dx.doi.org/10.1098/rspb.2010.2731

Fox, C.H., Paquet, P.C., \& Reimchen, T.E., (2013). Novel interactions between black bears and pacific herring, intertidal and terrestrial linkages. University of Victoria $\mathrm{PhD}$ dissertation.

Helfield, J.M., \& Naiman, R.J. (2006). Keystone interactions: salmon http://dx.doi.org and bear in riparian forests of Alaska. Ecosystems. 9(2), 167-180. ${ }^{/ 10.1007 / 11002}$

Hellgren, E.C. (1995). Physiology of hibernation in bears. Ursus. 10, 
467-477.

Hewitt, D.G. \& Robbins, C.T. (1996). Estimating grizzly bear food habits from fecal analysis. Wildlife Society Bulletin, 24(3), 547550.

Hocking, M.D. \& Reynolds, J.D. (2012). Nitrogen uptake by plants subsidized by Pacific salmon carcasses: a hierarchical experiment. Canadian fournal for Forest Research, 42, 908-917. http://dx.doi.org/10.

Hocking M.D. \& Reimchen, T.E. (2006). Consumption and distribution of salmon (Oncorhynchus spp.) nutrients and energy by terrestrial flies. Canadian fournal of Fisheries and Aquatic Sciences, 63, 2076-2086. http://dx.doi.org/10.1139/f06-110

Horn, H. (2009). EBM Working Group Focal Species Project - Part 3: Knowledge Base for Focal Species and their Habitats in Coastal B.C.

Howes, J. (1999). Application of a Bayesian belief network to model black bear intertidal habitat quality. University of Victoria Masters thesis.

Hristienko, H. \& McDonald Jr., J.E. (2007). Going into the 21st century: A perspective on trends and controversies on the management of the american black bear. Ursus, 17, 72-88. http://dx.doi.org/10.2192/1537-6176

Jaschinski, S. \& Sommer, U. (2010). Positive effects of mesograzers on epiphytes in an eelgrass system. Environmental Science and Pollution Research, 401, 77-88. http://dx.doi.org/10.3354/meps08412

MacHutchson, G.A. (1999). Black Bear Inventory, Clayoquot Sound, BC - Volume I: Habitat Inventory. B.C. Ministry of Environment, Land and Parks - Vancouver Island Region, Nanaimo, B.C.

Mattson, D.J., Blanchard, B.M., \& Knight, R.R. (1991). Food habits of Yellowstond grizzly bears, 1977-1987. Canadian fournal of Zoology, 69, 1619-1629. http://dx.doi.org/10.1139/z91-226

McCauley, D.J., DeSalles, P.A., Young, H.S., Dunbar, R.B., Dirzo, R., Mills, M.M. \& Fiorenza, M. (2012). From wing to wing: the persistence of long ecological interaction chains in less-disturbed ecosystems. Scientific Reports, 409(2), 1-5. http://dx.doi.org/10.1038/srep00409

Mealy, S.P. (1974). The natural food habits of grizzly bears in Yellowstone National Park. In M.R. Pelton (Ed.), A Selection of Papers 
from the Third International Conference on Bear Management, Moscow, Russia, June 1974. International Association for Bear Research and Management pp. 281-292.

Nowak, J., \& Crone, E.E. (2012). It is Good to be Eaten by a Bear: Effects of Ingestion on Seed Germination. American Midland Naturalist fournal, 167(1), 205-209. http://dx.doi.org/10.1674/0003-0031-167.1.205 Persson, I-L., Wikan, S., Swenson, J.E. \& Mysterud, I. (2001). The diet of the brown bear Ursus arctos in the Pasvik Valley, northeastern Norway. Wildlife Biology, 7, 27-47.

Quinn, T.P., Carlson, S.M., Gende, S.M. \& Rich, H.B. (2009). Transportation of Pacific salmon carcasses from streams to riparian forests by bears. Canadian fournal of Zoology, 87, 195-203. $\begin{aligned} & \text { http://dx.doi.org/ } \\ & 10.1139 / 209-004\end{aligned}$

Reimchen, T.E. (2000). Some ecological and evolutionary aspects of bear-salmon interactions in coastal British Columbia. Canadian fournal of Zoology, 78, 448-457. http://dx.doi.org/10.1139/z99-232

Rogers, L. (1976). Effects of mast and berry crop failures on survival, growth, and reproductive success of black bears. The 41st North American Wildlife and Natural Resources Conference. Wildlife Management Institute. Washington, D.C.

Smith, T.S. \& Partridge, S.T. (2004). Dynamics of intertidal foraging by coastal brown bears In Southwestern Alaska. Journal of Wildlife Management, 68(2), 238-240. http://dx.doi.org/10.2193/0022-541 (2004)068\%5B0

Vancouver Island - Regional Geography. (2013). Retrieved August 28th, 2013 from http://www.hellobc.com/vancouver-island/region al-geography.aspx 